\title{
Štovanje sv. Josipa u hrvatskoj crkveno-pučkoj baštini
}

Marko Dragić*

mdragic@ffst.hr

https://orcid.org/0000-0001-5362-6814 https:/doi.org/10.31192/np.18.1.11

UDK: 27-36JOS:27-53(497.5)

$27-312.45$

Pregledni članak / Review

Primljeno:14. rujna 2019.

Prihvaćeno: 8. veljače 2020.

U radu se govori o životu sv. Josipa Nazarećanina, muža Djevice Marije i nenaravnoga oca Isusa Krista. Evanđelja ne navode nijednu njegovu riječ, a ono što znamo o njemu sadržano je uglavnom u prva dva poglavlja Matejeva i Lukina evanđelja. Hrvatski sabor je 1687. godine proglasio sv. Josipa zaštitnikom Hrvatskog kraljevstva, a time i cijelog hrvatskog naroda. Zaštitnik je mnogih država, gradova, sveučilišta, bolnica, škola, crkava i drugih institucija. Takoder je zaštitnik je obitelji, očeva, djece, mladeži, siročadi, djevičanstva i čistoće, zaštitnik dobre smrti, konačišta i onih koji ih traže, putnika i prognanika, drvosječa, kolara, tesara, stolara, radnika i obrtnika, inženjera, doseljenika, umirućih i grobara. Svetkovina Sv. Josipa u hrvatskoj crkveno-pučkoj baštini slavi se pobožnostima, zavjetima, devetnicama, trodnevnicama, procesijama, svetim misama, pučkim slavljima. Za vrijeme turske okupacije hrvatske katoličke djevojke u dobi od 13 do 16 godina vršile su obred križićanja (tetoviranja križeva na rukama i/ili čelu i/ili prsima). Hrvatski katolički mladići križeve su tetovirali na ramenima da bi ih trajno podsjećali na njihovo podrijetlo i vjeru u slučaju da ih Turci odvedu u janjičare. Hrvatski katolički puk i sada od svojih predaka pamti $i$ kazuje usmene lirske pjesme o sv. Josipu. Kao višestrukom zaštitniku narod mu upućuje starinske molitve koje su molile naše davno upokojene pramajke i naši praočevi. Sv. Josipu se vjernici preporučuju u zajedničkim obiteljskim molitvama te u raznim prigodama.

Ključne riječi: molitve, preporuke, sv. Josip, usmene lirske vjerske pjesme, višestruki zaštitnik.

\footnotetext{
* Prof. dr. sc. Marko Dragić, red. prof. u trajnom zvanju, Sveučilište u Splitu, Filozofski fakultet, predstojnik Katedre za književnost i kulturu i voditelj Modula za književnost i kulturu na Poslijediplomskom doktorskom studiju humanističkih znanosti; Poljička 35, HR-21000 Split.
} 


\section{Uvod}

Iznimno važno mjesto u kršćanstvu pripada sv. Josipu, zaručniku Djevice Marije i hranitelju Isusa i Djevice Marije. Potomak je kralja Davida kome Bog obeća da će od njega poteći Mesija. Evanđelja ne navode niti jednu njegovu riječ, a ono što znamo o njemu sadržano je uglavnom u dva prva poglavlja Matejeva i Lukina evanđelja. Sv. Josip zaštitnik je Hrvatske, mnogih drugih zemalja, gradova, institucija. Zaštitnik je obitelji, očeva, djece, mladeži, siročadi, zaštitnik dobre smrti, putnika i prognanika, kolara, tesara, stolara, radnika i obrtnika, inženjera, doseljenika, umirućih i grobara i dr.

Međutim o sv. Josipu u hrvatskoj stručnoj i znanstvenoj literaturi iznimno je malo napisano. Luka Ilić Oriovčanin u svom djelu Narodni slavonski običaji (1846) uopće ne spominje sv. Josipa. Isto je i u djelu Mijata Stojanovića Slike iz domaćega života slavonskog naroda $i$ iz prirode, s dodatkom Slavonske pučke sigre (1858). Frano Ivanišević 1906. godine u svojoj monografiji Poljica, narodni život i običaji navodi samo izreku o sv. Josipu. Silvestar Kutleša u monografiji Život i običaji u Imockoj krajini (1934) navodi tri rečenice o običajima na svetkovinu sv. Josipa u Runovićima gdje je Kutleša bio župnikom. Milovan Gavazzi u svojoj knjizi Godina dana hrvatskih narodnih običaja (1939) navodi da su se uz sv. Josipa odvijali neki običaji i proricanja, ali ne navodi nijedan primjer. Međutim, u pamćenju naroda sačuvalo se sjećanje o običajima na svetkovinu sv. Josipa. Narod pamti i usmene lirske pjesme o sv. Josipu te starinske molitve tome velikom svetcu. $\mathrm{U}$ ovom radu je četrdesetak primjera običaja, pjesama i molitvi. Ti primjeri zapisivani su od 1994. do 2019. godine.

\section{1. Život sv. Josipa}

Josip na hebrejskom znači »Neka Bog pridoda«, a sv. Josip je potomak kralja Davida kome Bog obeća da će od njega poteći Mesija. »Od Abrahama do Davida četrnaest naraštaja; od Davida do progonstva u Babilon četrnaest naraštaja; poslije progonstva u Babilon do Krista četrnaest naraštaja« (Lk 3, 23-38). Bio je zakonski muž Marijin, iako ne i Isusov naravni otac. Matej navodi da je Josip bio tekton, što se najčešće prevodi kao tesar (građevinski radnik, zanatlija, stolar). ${ }^{1}$ Prema apokrifnoj predaji osamdesetogodišnji udovac Josip zaručio se s dvanaestogodišnjom Marijom. ${ }^{2}$

U Svetome pismu Josipu se uglavnom u snu javlja anđeo da mu dadne potrebne naputke: da se ne boji uzeti Mariju za ženu, jer »što je u njoj začeto, doista je od Duha Svetoga«. Vodio je svoju zaručnicu Mariju na popis stanovništva

\footnotetext{
${ }^{1}$ Usp. Mihael GLAZIER, Monika K. HELLWING (pr.), Suvremena katolička enciklopedija, Split, Marjantisak, 2005, 191.

${ }^{2}$ Usp. Erhard GORYS, Leksikon svetaca, Jastrebarsko, Naklada Slap, 2003, 200.
} 
iz Nazareta u Betlehem kojom se prilikom rodio Isus. Matej prikazuje Josipa kao »pravednog muža koji je uzor otvorenosti Bogu i vjere u Boga «. ${ }^{3}$

Prema jednom propisu Mojsijeva zakona, na uspomenu spašavanja od smrti izraelskih prvorođenaca, kada je pomor prvijenaca bio u Egiptu, prije izlaska Izraelaca iz Egipta, svaki prvijenac morao je u hramu biti posvećen Bogu na službu. Osim Levijeva plemena, svi prvorođenci drugih plemena morali su se u hramu otkupljivati posebnim prinosom od pet šekela namijenjenim za uzdržavanje svećenika i levita. Svećenik bi tada uzeo dijete i blagoslovio ga.

Prema drugom propisu, svaka je žena četrdeseti dan nakon rođenja muškoga djeteta morala doći u hram i prinijeti žrtvu za očišćenje. Ako je žena bila imućna morala je darovati janje i grlicu, a ako je bila siromašna morala je darovati dvije grlice ili dva golubića. Blažena Djevica Marija, kao majka Sina Božjega, nije imala tu obvezu, ali je dokazujući uzoran primjer izvršavanja Božjeg zakona, dragovoljno izvršila i taj Mojsijev propis. Četrdeset dana nakon Isusova rođenja Blažena Djevica Marija i sv. Josip donijeli su dijete Isusa u Jeruzalem, da ga ondje prikažu u hramu. Za otkupnu žrtvu prinijeli su dvije grlice ili dva golubića.

»Kad se zatim po Mojsijevu Zakonu navršiše dani njihova čišćenja, poniješe ga u Jeruzalem da ga prikažu Gospodinu - kao što piše u Zakonu Gospodnjem: Svako muško prvorođenče neka se posveti Gospodinu! - i da prinesu žrtvu kako je rečeno u Zakonu Gospodnjem: dvije grlice ili dva golubića (Mt 1, 22-24).

U hramu ih je dočekao Šimun kojemu je Duh Sveti objavio da neće umrijeti prije nego što vidi Spasitelja. Šimun je uzeo Isusa i zapjevao hvalospjev:

»Sad otpuštaš slugu svojega, Gospodaru, po riječi svojoj, u miru! Ta vidješe oči moje spasenje tvoje, koje si pripravio pred licem svih naroda: svjetlost na prosvjetljenje naroda, slavu puka svoga izraelskoga« (Mt 1, 29-32).

Blažena Djevica Marija i sv. Josip iznenadili su se Šimunovim riječima i čudili se kako je on znao tajnu. Šimun ih je blagoslovio i rekao Mariji:

»Ovaj je evo postavljen na propast i uzdignuće mnogima u Izraelu i za znak osporavan - a i tebi će samoj mač probosti dušu - da se razotkriju namisli mnogih srdaca!« (Mt 1, 34-35). ${ }^{4}$

»A bijaše neka proročica Ana, kći Penuelova, iz plemena Ašerova, žena veoma odmakla u godinama. Nakon djevojaštva živjela je s mužem sedam godina, a sama kao udovica do osamdeset i četvrte. Nije napuštala Hrama, nego je postovima i molitvama danju i noću služila Bogu. Upravo u taj čas nadođe. Hvalila je Boga i svima koji iščekivahu otkupljenje Jeruzalema pripovijedala o djetetu« (Mt 1, 36-38).

\footnotetext{
${ }^{3}$ Usp. Glazier, Hellwig (pr.), nav. dj., 191.

${ }^{4}$ Usp. Janko OBERŠKI, Biblijska povijest Staroga i Novoga zavjeta, Split, Marjantisak, 2005, 98.
} 
Josipu se u snu javio anđeo i rekao mu da bježi u Egipat pred Herodom koji želi ubiti Isusa. Kad je prošla opasnost anđeo se u snu javio Josipu da se vrati u Nazaret. Kad je umro Herod ${ }^{5}$ anđeo se u snu javio Josipu u Egiptu:

»'Ustani, reče, uzmi dijete i njegovu majku te pođi u zemlju izraelsku jer su umrli oni koji su djetetu o glavi radili.' On ustane, uzme dijete i njegovu majku te uđe u zemlju izraelsku. Ali saznavši da Arhelaj vlada Judejom namjesto svoga oca Heroda, bojao se poći onamo pa, upućen u snu, ode u kraj galilejski. Dođe i nastani se u gradu zvanu Nazaret - da se ispuni što je rečeno po prorocima: Zvat će se Nazarećanin« (Lk 2, 20-23).

Josip i Marija svake godine o blagdanu Pashe išli su u Jeruzalem. Kad je Isusu bilo dvanaest godina nakon toga blagdanskoga običaja vraćali su se, a dječak Isus ostao je u Jeruzalemu. Njegovi roditelji to nisu znali pa su ga tražili. Kada su od Jeruzalema otišli daleko dan hoda bili su uvjereni da je sa suputnicima pa su ga tražili među rodbinom i znancima, a kad ga nisu našli vratili su se u Jeruzalem tražiti ga:

»Nakon tri dana nađoše ga u Hramu gdje sjedi posred učitelja, sluša ih i pita. Svi koji ga slušahu bijahu zaneseni razumnošću i odgovorima njegovim. Kad ga ugledaše, zapanjiše se, a majka mu njegova reče: 'Sinko, zašto si nam to učinio? Gle, otac tvoj i ja žalosni smo te tražili.' A on im reče: 'Zašto ste me tražili? Niste li znali da mi je biti u onome što je Oca mojega?' Oni ne razumješe riječi koju im reče« (Mt 1, 46-50).

Nakon toga događaja s Isusom u hramu Josip se više ne spominje. Vjerojatno je nakon toga ubrzo umro. Prema katoličkoj predaji umro je na rukama Isusa i Marije. 6

\subsection{Višestruki zaštitnik}

Papa Siksto IV. je 1479. godine uveo svetkovinu sv. Josipa. Klement XI. je 1714. godine tu svetkovinu propisao za cijelu Katoličku crkvu. Benedikt XIII. 1729. je sv. Josipa uvrstio u litanije Svih svetih, a Pio XII. je 1955. godine kao blagdan sv. Josipa Radnika odredio 1 svibnja. $^{7}$

Sv. Josip je dostojan velike časti koju mu je ukazao sam Bog odabravši ga za brižnog čuvara i skrbnika najsvetije obitelji. Pred ljudima je Isus bio njegov i za njega je on odgovarao. Bio je pravedan muž, čovjek vjere i poslušnosti, čovjek dobra srca. Velika je snaga njegova zagovora kod Boga. Hrvatski sabor je 1687. godine proglasio sv. Josipa zaštitnikom Hrvatskoga kraljevstva, a time i cijeloga hrvatskog naroda. U prosincu 1870. godine papa Pio IX. proglasio je sv.

\footnotetext{
${ }^{5}$ Heroda je stigla strašna kazna. Obolio je od bolesti u kojoj su ga živa izjedali crvi i umro je u strašnim mukama (usp. Oberški, nav. dj., 100).

${ }^{6}$ Usp. $O$ sv. Josipu, http://www.svetijosip.com/index.php/sveti-josip/o-svetom-josipu (02.08.2019).

7 Usp. Gorys, nav. dj., 200-201.
} 
Josipa zaštitnikom sveopće Crkve. Zaštitnik je Austrije (1675.), Češke (1654.), Kanade (1624.), Meksika (1555.), Perua (1828.). Također je zaštitnik Belgije, Južne Koreje, Kine, Vijetnama i dr. ${ }^{8}$ Zaštitnik je mnogih gradova, sveučilišta, bolnica, škola, crkava i drugih institucija. Najveće svetište sv. Josipa nalazi se u Montrealu u Kanadi. U Hrvatskoj je najveće svetište sv. Josipa u Karlovcu. Red Sestre svetoga Josipa osnovan je 1650. godine i diljem svijeta broji oko 14.000 sljedbenica, a red Oci i braća sv. Josipa osnovan je 1871., s nakanom da rade sa siromašnima. ${ }^{9}$ Zaštitnik je obitelji, očeva, djece, mladeži, siročadi, djevičanstva i čistoće, zaštitnik dobre smrti, konačišta i onih koji ih traže, putnika i prognanika, drvosječa, kolara, tesara, stolara, radnika i obrtnika, inženjera, doseljenika, umirućih i grobara. ${ }^{10}$ Svetkovina sv. Josipa je 19. ožujka i blagdan 1. svibnja. Mjesec ožujak posvećen je sv. Josipu, a srijeda je dan sv. Josipa. U ikonografiji sv. Josip prikazuje se kao bradati stari tesar s oruđem: sjekirom, teslom, pilom, kutomjerom itd. Također se prikazuje kako nosi dijete Isusa, u ruci drži ljiljan ili putnički štap iz kojega cvjeta ljiljan (čudo sa štapom za vrijeme bijega u Egipat). ${ }^{11}$

\section{Pobožnosti i običaji uz sv. Josipa}

Premda je svetkovina sv. Josipa najčešće u korizmi taj dan u hrvatskoj kulturnoj baštini dopušteno je proveseliti se i proslaviti velikoga sveca. Toga dana nije obvezan post, skupljaju se na sijela, mladi se zabavljaju. Runovićani svetkuju sv. Jozipa, a sve do mise ispovijedaju se starci. Na Blagovijest se ispovijedaju starice. Težački posao se nije obavljao. ${ }^{12}$ U Hercegovini sv. Josip se svugdje slavi i smatra se zaštitnikom bijednoga seljaka koji se stoljećima tješio i radovao njegovoj svetkovini jer tada trava počinje rasti, stoka neće ugibati od gladi, a sv. Josip će »pokupiti sve mišine«. Stoga sv. Josipa nazivaju »kupimišinar.$^{13} \mathrm{U}$ Poljicima je Josipovo velika svetkovina. Smatra se da je s tom svetkovinom zima utekla, ali se pokatkad zna vratiti pa se govorilo: Sveti Josip snigon posip, sveti Bene ${ }^{14}$ snigon krene. Sveti Bene omendule ${ }^{15}$ bere. ${ }^{16}$ Stara je kreševska tradicija

\footnotetext{
${ }^{8}$ Usp. isto, 200.

${ }^{9}$ Usp. O sv. Josipu...

${ }^{10}$ Usp. Gorys, 200.

${ }^{11}$ Usp. isto, 201.

${ }^{12}$ Usp. Silvestar KUTLEŠA, Život i običaji u Imockoj krajini, Imotski, Matica hrvatska - Ogranak Imotski, 1997, 276.

${ }^{13}$ Jerko SUTON, Vjerski život i običaji Zapadne Hercegovine, Mostar 1968, 112. (Umnožen rukopis. Primjerak se nalazi u Franjevačkoj knjižnici Mostar, inv. br. 3912, sign. 39).

${ }^{14}$ Sveti Bene - sv. Benedikt.

${ }^{15}$ Omendula (mendula) - bajam, badem. Mendule procvjetaju koncem veljače.

${ }^{16}$ Frano IVANIŠEVIĆ, Poljica, narodni život i običaji, reprint izdanja JAZU iz 1906. i neobjavljena građa, Split, Književni krug Split, 1987, 445-446.
} 
da se mladež okupi na brdu $\operatorname{Grad}^{17}$ gdje je boravila posljednja bosanska kraljica Katarina Kosača Kotromanić. Mladež bi na svetkovinu sv. Josipa pjevala Gospin plač. ${ }^{18} \mathrm{U}$ mnogim mjestima prije svetkovine u crkvi se obavlja devetnica $u$ čast sv. Josipa. Nekada su to, primjerice u Iloku, bile večernjice, a poslije obnove liturgije, slavi se večernja sveta misa s moljenjem Litanija sv. Josipa i pjevanjem $\mathrm{u}$ čast ovog sveca. ${ }^{19}$ Općenito je narodno vjerovanje da proljeće počinje svetkovinom sv. Josipa. Gavazzi piše i da se uz sv. Josipa vezuje nešto vjerovanja i proricanja, ali ne navodi nijedan primjer. ${ }^{20}$

\subsection{Križićanje}

U vrijeme turske ${ }^{21}$ okupacije, kad su age i turski gospodari bili strah i trepet katoličkom pučanstvu, posebno ženskom stanovništvu, žene su vjerovale da ih samo Bog može u tome sačuvati. Zato su još od rane mladosti crtale križeve po rukama. U Splitu se pripovijeda kako su Turci upadali u cincarska sela i otimali djecu, uglavnom žensku. Tako od nekog bogatog Cincara beg zatraži kćer za ženu. Otac nije smio odbiti bega pa mu je rekao da dođe nakon mjesec dana kad sve bude spremno za svadbu. Djevojci su istetovirali križ na čelu pa je beg nije mogao uzeti za ženu. Otada su sve cincarske djevojke tetovirale križ na čelu i na rukama. Taj događaj i danas je u narodnom pamćenju:

»A cili taj običaj krenija ti je iz jednog sela, tu pokraj granice di je jedan beg zatražija od nekog bogatuna ćer za ženu. A taj bogatun nije moga odbit bega jer bi ovaj ubija i njega i ženu i dicu mu, pa mu je tako reka da dođe za misec dana kad sve bude spremno da se ženu. U to vrime oni su divojci istetovirali veliki križ nasri' čela i tako ju beg nije moga uzet. Otad se to proširilo po svim selima i sve su žene to radile.« ${ }^{22}$

Križićanje (sicanje, bocanje, tetoviranje) najčešće su primjenjivali mladići i djevojke između 13. i 16. godine. Običaj tetoviranja bio je najviše rasprostranjen među hrvatskim katoličkim življem središnje Bosne, osobito na teritoriju bivšeg visočkog, fojničkog, sarajevskog, travničkog, bugojanskog, prozorskog kotara i niz donji Vrbas, kotorvaroški i banjolučki kraj. Na južnoj i istočnoj periferiji tih područja, primjerice u Olovu, Varešu, Vijaci i u dolini Neretvice

\footnotetext{
${ }^{17} \mathrm{Na}$ tome mjestu i danas se vide zidine nekadašnjega Grada.

${ }^{18}$ Zapisao sam koncem prosinca 1994. godine u Kiseljaku. To su moji terenski zapisi koje mi je kazivalo više kazivača i/ili kazivačica i nalaze se u vlastitoj rukopisnoj zbirci, u daljnjim bilješkama navodit će se kao Vl. rkp. zb.

${ }^{19}$ Mato BATOROVIĆ, Iločki list, 2 (travanj, 1995) 13, 11.

${ }^{20}$ Milovan GAVAZZI, Godina dana hrvatskih narodnih običaja, Zagreb, Hrvatski sabor kulture, ${ }^{3} 1991,24$.

${ }^{21}$ Narod uvijek spominje Turke. Sukladno tomu u ovom radu se koristi naziv Turci, a ne Osmanlije.

${ }^{22}$ Usp. Marko DRAGIĆ, Danak u krvi u romanu »Na Drini ćuprija« i u suvremenom pripovijedanju, HUM - časopis Filozofskoga fakulteta Sveučilišta u Mostaru, 8 (2012) 126-127.
} 
»svijet samo još za to tetovira, da zadovolji formi«. U tim krajevima uglavnom bi križić istetovirali na ramenu. U sjeverozapadnim područjima koncem 19. stoljeća taj običaj bio je veoma čest. ${ }^{23}$

Na Josipovo, Blagovijest, Cvjetnicu i u dane Velikoga tjedna te na Ivandan, skupila bi se ujutro mladež i cijela familija. Ako osoba ne bi voljela tetoviranje obaviti sama sebi tada bi to preuzimala žena iskusna u toj vještini ili bi to uzajamce obavljali prijatelji i prijateljice. Ornament bi se najprije tupim krajem igle zamočenim u posebno pripravljeno crnilo od čađi luča ili obične čađi nacrtao na koži, a potom bi se šiljastim kraja rta bockalo. Čađ od luči pomiješala bi se s mladim medom i vodom i mazala po rani. Da se crtež ne bi osušio, preko njega se više puta navlačilo crnilo. (Za crnilo se pokatkad kupovao murećef kojim su muslimani pisali.) Mladići i djevojke s radošću su se podvrgavali iznimno bolnom tetoviranju. Po svršetku tetoviranja rana bi se obložila svilenim ili voštanim papirom i već sljedećega dana ona se mogla prati hladnom vodom. ${ }^{24}$

Najljepše oblike tetoviranja Truhelka je našao $u$ dolini Lašve, posebice $u$ mjestima oko Gučje Gore te više-manje i u susjednim kotarima na sjeveru do Banje Luke, a na jugu do ramske doline i Kupresa. »U tim je krajevima jezgra katoličkog žiteljstva, pa je po tome to područje najviše proširenog tetoviranja paralelno najjačem području katolicizma u Bosni. « ${ }^{25}$ Tetoviranje križeva bilo je općenit običaj među katolicima u okolici Prizrena, Đakovice i Peći, »pa sam dosta puta imao prilike viđati tetoviranu čeljad iz Prizrena, Janjeva i Prištine «. ${ }^{26}$ Starije žene pripovijedaju da su se na Dan sv. Josipa djevojke i mladići, u dobi od trinaest do šesnaest godina, križićali. Pored svetkovine sv. Josipa (19. ožujka) križićalo se i na Blagovijest (25. ožujka), Cvjetnicu, u dane Velikoga tjedna, na Jurjevdan (23. travnja) i na Ivandan (24. lipnja).

U jednoj zdjelici zamiješao bi se med i usitnjeni ugljen od izgorenog drveta. Prah je trebao biti sitan. Kad bi se pomiješao s medom, dobivala bi se crna smjesa. Tada su bake i mlade žene iglom zamočenom u tu smjesu crtale križeve po rukama. Kad bi ih nacrtale, onda su ponovno manjom iglom bockale to ucrtano mjesto. Ta smjesa ulazila je pod kožu. Postupak se ponavljao i nekoliko puta dok bi ta crna smjesa ostala plavkasta na koži. Ranice bi zarasle i crteži križa ostajali su za cijeli život. Vjerovalo se da ih ti križevi štite od napasnika. Čuvalo se poštenje i ponos. S tim se križevima i umiralo i svaka od njih je vjerovala da ju je samo Bog tako zaštitio od napasnika. ${ }^{27}$

Unutar korizme slavi se svetkovina sv. Josipa i Blagovijest. To su veće svetkovine i tada se igra kolo i narod se veseli. Tada su se u kreševskom kraju bocali

\footnotetext{
${ }^{23}$ Usp. Ćiro TRUHELKA, Tetoviranje katolika u Bosni i Hercegovini, Glasnik zemaljskog muzeja u Bosni i Hercegovini, knj. II, god. VI, Sarajevo, 1894, 241-257.

${ }^{24}$ Usp. isto.

${ }^{25}$ Usp. isto.

${ }^{26}$ Isto.

${ }^{27}$ Usp. Marko DRAGIĆ, Nematerijalna kulturna baština Hrvata u Bosni i Hercegovini, Bosna franciscana 45 (2016) 265-314.
} 
križevi, zvijezde i cvjetovi na rukama. Malina Kraljević (djev. Filipović), rođ. 1937. godine u Crkvenjaku kod Kreševa 1994. godine pripovijedala je da je sama sebi utetovirala križ. Sâm proces bocanja bio je jako kompliciran, ali na području Kreševa svaka starija baka ima križ, što je bila potvrda da je iz kršćanske obitelji i da ima sve moralne vrijednosti te baštine. Bocanje križa bilo je sjećanje na vremena višestoljetne turske okupacije, kada se provodio zakon Danak $u$ krvi (Adžami-oglan). Turci su uzimali mušku djecu i odvodili ih u roblje. Zato su muškoj djeci kasnije tetovirani križevi, kako bi, ako budu odvedeni, ipak bili svjesni svoga kršćanskog podrijetla. Kasnije je tetoviranje križeva prošireno i na žensku djecu, a križ je imao ulogu zaštite od turskih napasnika. ${ }^{28}$

O svetkovini sv. Josipa u Rami su se cure križićale. Turci su provodili gnjusno pravo prve bračne noći. Zato su matere, čim bi cura stasala za ašikovanje, negdje gdje se dobro vidi: na ruci, na prstu, pa i na čelu nasicale križić da se znade da je kršćanka, a i da je križ obrani od Turaka. To bi se radilo o Sv. Josipu jer bi rekli da se tada rana neće dati na zlo. Samo su neke žene znale sicati, pa bi se onda kod te žene sakupilo puno cura. Prvo bi se nacrtalo što hoće da se nasica, a onda bi žena zategla kožu i brzo bola po tom mjestu, prema nacrtanom. Onda bi uzela čađi i meda, izmiješala i namazala. Znala bi se i rana napraviti, ali nije se nitko bunio..$^{29} \mathrm{Na}$ Śćitu u Rami, za vrijeme turskog vakta ${ }^{30}$ na svetkovinu sv. Josipa naložila bi se vatra od čistog luča, od borovine, i kad bi se naložila vatrica, stavio bi se nad vatru neki tvrdi karton da se uhvati malo čađe i onda bi se to izmiješalo s dvije-tri kapi vode i uzelo bi se neko drvo poput čačkalice i nacrtao bi se križ. Potom bi se uzela iglica i polako bi se bockalo. Krv bi malo pokvasila i to bi se još jednom ponovilo i onda bi križ ostao trajno. Turci su htjeli prvu bračnu večer spavati s našim mladama i zato su se sicali križevi jer Turci nisu voljeli spavati s onima koje su imale na sebi križeve. Zato bi većina sicala te križeve da se oslobode turskoga zuluma. ${ }^{31}$

U busovačkom kraju mladima su križeve tetovirale starije djevojke koje su bile hrabrije i upućenije ili neke bake koje su bile dobro naučene. Starije žene pripovijedaju da su se kao djevojke malo bojale tetoviranja, ali im je bilo i drago jer su nakon toga smatrane odraslim djevojkama i tada su mogle ići na prela. ${ }^{32}$ Anđa Marić, rođena 1929. godine u selu Podjela kod Busovače, 2006. godine pripovijedala je da se običaj tetoviranja počeo gubiti kad je ona bila mlada. Kada bi se odlučilo tetovirati, odmah bi se počelo razmišljati koga će se zvati da radi crteže jer se znalo da je to za vijeke vjekova pa su svi htjeli da im ornamenti

\footnotetext{
${ }^{28}$ Zapisao sam koncem prosinca 1994. godine u Kreševu, Vl. rkp. zb.

${ }^{29}$ Kazala mi je 1997. godine na Gmićima u Rami Jela Lovrić (rođ. 2. veljače 1938. - † 9. studenoga 2019.), Vl. rkp. zb.

${ }^{30}$ Väkat - vrijeme, doba (Ante KRALJEVIĆ, Ričnik zapadnoercegovačkoga govora, Široki Brig - Zagreb, Matica hrvatska, Ogranak Široki Brijeg - DAN, 2013, 395). U narodnom govoru sinonim za riječ vakat je zèmān (isto, 426).

${ }^{31} \mathrm{Na}$ Šćitu u Rami zapisao sam 1997. godine, Vl. rkp. zb.

${ }^{32}$ Prelo - sijelo, zabava.
} 
budu što ljepši. Djevojke i žene koje su tetovirale križeve bile su iznimno cijenjene. U busovačkom kraju tetoviranje se obavljalo najčešće na svetkovinu sv. Josipa. Mladež koja bi čekala da dođu na red za tetoviranje stajali bi sa strane i pjevali staru pjesmu:

Zanatlijo tihi,
k'o oca te svog
poštivao Bog.
Ti zaručnik Djevin,
o Josipe svet,
o Josipe svet!
Dušmana nas tamnih
saletio roj,
nav'jestio boj;
u gr'jesima hoće
da utopi sv'jet,
o Josipe svet. ${ }^{33}$

U Gučoj Gori i okolici križićanje se zvalo tetoviranje ili bocanje. Obično je obuhvaćalo ruke i prsa, a neki ljudi su imali i jednostavan motiv na čelu, ali on je bio prilično rijedak. Većinom su se tetovirale žene, a muškarci rjeđe. Kod žena je bila našarana gornja strana ruke, pregib, ruka ispod lakta, a često i nad laktom. Tetoviranje je često produženo i na donju stranu ruke. Prsa su se obično tetovirala nasred grudne kosti. Bocanje se obavljalo u dobi između trinaeste i šesnaeste godine. Prikazivani su različiti motivi: krug, sunce, jelica, vijenac, grančica, klas i drugo, ali najčešći je bio motiv križa. Simbolika motiva nedvojbeno svjedoči da je obilježavanje djece trajnim križićima ovdašnjem puku služilo kao sredstvo otpora turskoj tiraniji. Tim se činom nastojalo zaustaviti odvođenje muške djece $u$ janjičare i prijelaz na islam te spriječiti prisilno udavanje kršćanskih djevojaka za Turke, odnosno njihovo odvođenje u roblje, hareme ili da prvu bračnu noć provedu s agom ili begom.

Tetoviranje se obavljalo tako što bi se ujutro okupila mlađarija jedne obitelji i otpočelo bi tetoviranje. Ako nekoj osobi nije bilo draže da taj posao sama obavi, onda bi taj posao preuzela starija žena, koja je u tome dostigla osobitu vještinu. Mladež se velikom radošću podvrgavala toj bolnoj operaciji. Najprije bi se na koži tupim krajem igle zamočenim u posebno pripravljeno crnilo nacrtao ornament, pa bi se onda po crtežu bockalo, dok ornament ne bi bio gotov. Da se crnilo ne bi osušilo, više bi se puta crtež navlažio crnilom. Nakon toga, rana bi se svilenim papirom (papirom za cigarete) ili voštanim papirom

\footnotetext{
${ }^{33}$ Branka Bagarić zapisala je u selu Podjela kod Busovače. Kazala joj je Anđa Marić, djev. Vujica, rođena 1914. Nije završila nijedan razred škole (usp. Branka Bagarić, Hrvatska tradicijska kultura i književnost u suvremenoj etnografiji busovačkog kraja, diplomski rad, Mostar, Filozofski fakultet Sveučilišta u Mostaru, 2007, 72-73).
} 
obložila i zavila. Drugi dan rana se smjela oprati hladnom vodom. Kod drugoga načina tetoviranja zapalio bi se gaz (petrolej) i saja (čađ) koja bi se pomiješala s pčelinjim medom i od toga bi se napravila maza $^{34}$ (mast). Zatim se iglom bocalo po rukama po prethodno odabranim i iscrtanim simbolima. ${ }^{35}$

U Kraljevoj Sutjesci i okolnim selima tetoviranje križeva zvalo se bocanje križeva. Taj običaj počeo je za vrijeme turske okupacije jer bi aga ili beg prvi spavao s kršćankama. Stoga su se bocali križevi. Koja je žena imala križ na ruci $\mathrm{s}$ tom nisu spavali. ${ }^{36}$ Proces bocanja križeva odvijao se tako što bi se naložio luč. Peruškom bi se u jednu posudicu ili čašu pokupio pepeo. Po kap vode se stavljala da se to razmuti. Uzela bi se tanka igla i s njom su se bocali križevi. Kad bi se smjesa stavila pod kožu uzimao se papir koji bi se izbockao i stavio na ranu. Sutradan se taj papir skidao. Bockalo se na rukama i prsima. Ta stara tradicija prekinuta je pedesetih godina 20. stoljeća. ${ }^{37}$

U Jajcu i okolici na svetkovinu sv. Josipa uzimalo se smole i čađi pa bi se to prokuhalo i onda se po rukama mazalo i iglama se bolo. Preko noći bi se to zamotalo i izjutra bi ostale tetovaže. ${ }^{38}$

Za vrijeme turskoga vladanja u Bosni i Hercegovini i na području Maglaja mlade katolkinje su njihove obitelji skrivale od turskih vojnika koji su uvijek koristili svoj položaj da bi zlostavljali katolike, silovali djevojke i žene. Turci su katoličke djevojke otimali i vodili ih u svoje tabore, gdje su im bile prisilne ljubavnice. Stoga su djevojke tetovirale križ na podlaktici. Taj običaj se zadržao jako dugo na području Bosne i Hercegovine da bi se mlade djevojke očuvale od obeščašćenja. ${ }^{39}$

U Prološcu Donjem kod Imotskoga postupak tetoviranja bio je sljedeći: oštrom iglom bi se bockala koža pa se u ranice ubrizgavala boja da se na koži trajno vidi križ - simbol krštene duše. Tetoviranje je uzelo maha za vrijeme turske okupacije. Turci su vršili razne zulume te bi, između ostalog, hvatali kršćanske djevojke i žene te ih silovali. Da bi se to nasilje spriječilo, jedini način je bio da se na rukama utetovira više manjih križića, a na prsima malo veći križ. Znalo se da Turci bježe od križa i da nikada ne bi dotakli rukom ruke kršćanke na kojoj bi ugledali križ ili prsa na kojima bi bio još veći križ. Čak su i majke

\footnotetext{
${ }^{34}$ Máza - ljekoviti pripravak kojim se mažu rane (usp. Kraljević, nav. dj., 177).

${ }^{35}$ Danijela Gučanin zapisala je 2010. godine. Kazivala joj je Ludvina Vrhovac, rođena 1934., djev. Marinić (usp. Danijela Gučanin, Hrvatska usmeno-književna i etnološka baština Lašvanske doline, diplomski rad, Mostar, Filozofski fakultet Sveučilišta u Mostaru, 2010, 50-51).

${ }^{36}$ Kao zaštita od prava prve bračne noći svadbe su se pravile u velikom broju na svetkovinu sv. Katarine Aleksandrijske [usp. Marko DRAGIĆ, Sveta Katarina Aleksandrijska u hrvatskoj katoličkoj tradicijskoj baštini, HUM - časopis Filozofskoga fakulteta Sveučilišta u Mostaru, 7 (2011) 264-265].

${ }^{37}$ Zapisao sam 2004. godine u Ćatićima kod Kaknja, Vl. rkp. zb.

${ }^{38}$ Zapisao sam 1999. godine u Jajcu, Vl. rkp. zb.

${ }^{39} \mathrm{U}$ Korenici 2013. godine priopćila mi je kazivačica koja je izbjegla iz Maglaja u Bosni i Hercegovini, Vl. rkp. zb.
} 
svoje mlade kćeri tetovirale, i to obavezno na šaci zbog toga što je to bilo jedino uvijek vidljivo mjesto na koži zbog običaja nošenja dugih rukava. ${ }^{40}$

Osamdesetdvogodišnji Marko Katić 2019. godine u Lokvičićima ${ }^{41}$ je pripovijedao da je njegova mater imala jedan veći križ na ruci. Dok je bio još malo dijete, nije o tome toliko razmišljao jer je mislio da je to nešto normalno. Vidio je da to ima većina žena po selu. Počeo se zanimati što je to i mater mu je objasnila da je to svaka cura trebala imati od straha zbog napada Turaka. Turci su radili razne zulume. Otimali su i silovali katolkinje. Da ne bi to doživljavale, crtale su križeve, jer su se Turci grozili križeva kao i samog kršćanstva i bježali bi kada bi to vidjeli. Mater mu je rekla da je njoj njezina mater nacrtala križ kad je imala 13 godina. Najviše se križićalo na svetkovinu sv. Josipa, ali i na Cvitnicu i na Ivandan. Proces je bio takav da bi se zamiješao med i ugljen od izgorenog drveta $u$ jednoj zdjeli. Prah je trebao bit sitan i kad bi se pomiješao $s$ medom, dobivala bi se crna mješavina. Tada bi se uzela igla i zamočila u tu mješavinu i crtali bi se križevi. Kazivač se sjeća da mu je mater rekla da je to puno boljelo i da je plakala. Kad bi se nacrtao križ, onda bi se opet iglom bockalo to ucrtano mjesto. To se sve radilo da bi proces uspio i da bi ta crna mješavina uspjela ući skroz pod kožu. Križevi bi potom ostajali za cijeli život. Vjerovalo se da je tako samo dragi Bog zaštitio žene i djevojke od napasnika. ${ }^{42}$

U Ogorju ${ }^{43}$ su djevojke i mladići tetovirali križiće. Činili su to kao znak potvrde svoje kršćanske vjere:

»Iglicon bi napravile križiće po ruci, po prstima, kako bi ko moga izdržat, smrvi ugljena, ugusto ga zamišaj sa vodon pa iglicon zabilježi križić, to bi bolilo. To smo mi cure i momci radili, pretežno curice do jedno petnaest, šesnaest godina, to nije smetalo roditeljima, niko ti nije smeta. ${ }^{44}$

Tradicija križićanja prekinuta je pedesetih godina 20. stoljeća. U novije vrijeme, od prije desetak godina, mladi, primjerice u Rami, suvremenom tehnikom tetoviraju križeve po rukama i prsima.

\subsection{Simbolika igre kapica (prstena)}

U Majdanu kod Mrkonjić Grada na svetkovinu sv. Josipa pije se crno vino i vjeruje se: koliko se vina popije toliko će se krvi dobiti. ${ }^{45} \mathrm{Na}$ sijelima su i stari

\footnotetext{
${ }^{40}$ Zapisao sam 2003. godine u Prološcu Donjem kod Imotskoga, Vl. rkp. zb.

${ }^{41}$ Lokvičići je općina kod Imotskoga.

${ }^{42}$ Studentica kroatistike na Filozofskom fakultetu u Splitu Paola Katić zapisala je 2019. godine i navela u svom seminarskom radu iz kolegija Hrvatska usmena književnost. Kazao joj je njezin djed Marko, u selu poznat pod nadimkom Markica. Rođen je 10. listopada 1937. god. u Lokvičićima gdje je odgojen i odrastao kao najstarije dijete u sedmeročlanoj obitelji.

${ }^{43}$ Ogorje (Donje i Gornje) pripada općini Muć, udaljeno je od Splita četrdesetak kilometara.

${ }^{44}$ Zapisao sam 2016. godine u Bračevićima kod Ogorja, Vl. rkp. zb.

${ }^{45}$ Vino je simbol Isusove muke i krvi. U Dalmaciji, Lici, Srijemu, Bačkoj, Rami i Hercegovini vjerovalo se da se vino popijeno na Veliki petak pretvara u krv. U Bačkoj se isto vjerovalo i za
} 
i mladi igrali kapica. Svaki igrač je trebao imati kapu ispred sebe i uzeli bi od nekoga vjenčani prsten. Jedan igrač uzeo bi prsten u ruku i ruku zavlačio pod svaku kapu, ostavio bi prsten ispod jedne, ostali su trebali pogoditi ispod koje je kape i tko pogodi on sljedeći skriva prsten. Igra s prstenom povezivala se sa svetkovinom sv. Josipa jer je on bio zaručnik Marijin i zaštitnik obitelji. ${ }^{46}$

\subsection{Velolučka tradicija}

Velolučani posebno štuju svoga zaštitnika svetoga Jozipa. Toga dana se ne fatiga. ${ }^{47}$ Po mjestu se ide u procesiji i na velu misu.

»Dan prin tega, svi kumpanjoni iz Kumpanije ${ }^{48}$ dođu u crikvu da im svećenik podijeli blagoslov, apozito ${ }^{49}$ novima dužnosnicima, kako bi boje izveli sutrašnji boj. Na sami dan Sv. Jozipa, sat prije nego Kumpanija nastupi, kumpanjoni idu po barjaktara, a potom po kapetana, koji ih čekaju u svojim domovima. Užan$c a^{50}$ je da u barjaktara i kapetana kumpanjone dočeka tratamenat..$^{51}$ Kad malo založe ${ }^{52}$ cila kumpanija se uputi na pijacu, isprid Vele crikve, izvest Ples od boja sa svima puntima. ${ }^{53}$ Toga dana folklorna skupina Mafrina tanca svakakve stare velolučke tance. ${ }^{54} \mathrm{Kad}$ Kumpanija svrši Ples od boja, djevojke i žene iz Mafrine izvedu starinski ples Tanac, kojega tancaju s muškima iz Kumpanije, a mješovita klapa kanta..$^{55}$ Muškardini ${ }^{56}$ su dreti ${ }^{57}$ kao sviće, imaju lipe odore i žinske ${ }^{58}$ lipe nošnje. Profita ${ }^{59}$ jih je gust gledat. A koliko tek force ${ }^{60}$ imaju, pogotovo barjaktar

vino popijeno na Blagovijest, a u Rami za Badnjak.

${ }^{46}$ Antonela Kovčalija zapisala je 2009. godine u Glamoču. Kazale su joj Marija Kelava, djev. Deljak, rođena 1938. godine u Majdanu i Franka Kovčalija, djev. Jurić, rođena 1943. godine u Majdanu. Kazivačice su prognanice iz Majdana i žive u Glamoču. Antonela Kovčalija, Hrvatska usmeno-književna i etnološka baština u Majdanu, diplomski rad. Mostar, Filozofski fakultet Sveučilišta u Mostaru, 2009, 41.

${ }^{47}$ Fatigati - raditi.

${ }^{48} \mathrm{Na}$ Korčuli Kumpanije postoje u mjestima: Blato, Čara, Pupnat, Smokvica i Žrnovo. U Veloj Luci Kumpanija je osnovana je 1846. godine. Radom je prestala 1926. godine, a 7. lipnja 2001. godine održana je osnivačka skupština Folklornog društva Kumpanija. To društvo njeguje tradicionalne velolučke plesove: Mafrina, Četiri pasa, Tanac, Pritilica, Šega-šega, te posebice atraktivan ples s mačevima poznat pod nazivima Ples od boja ili jednostavno Kumpanija. Glavni im je nastup na svetkovinu sv. Josipa, zaštitnika Vele Luke. Folklorno društvo KUMPANIJA; http://www.velaluka.hr/vela_luka.asp?id=16 (03.09.2019).

${ }^{49}$ Apozito - posebno.

${ }^{50}$ Užanca - navika, običaj.

${ }^{51}$ Tratamenat - zakuska.

${ }^{52}$ Založiti - prizalogajiti, malo pojesti.

${ }^{53}$ Puntima - potezi (u ovom kontekstu).

${ }^{54}$ Tanci - plesne zabave.

${ }^{55}$ Kantat - pjevati.

${ }^{56}$ Muškardin - muškarac.

${ }^{57}$ Dreti - ravni.

${ }^{58}$ Žinske - ženske.

${ }^{59}$ Profita - zaista.

${ }^{60}$ Forca - snaga. 
kad ono vije naš hrvaski barjak. Svi događaji isprid crikve finiju ${ }^{61}$ do večernje mise. Nakon toga Kumpanija, Mafrina i klapa po užanci gredu ${ }^{62}$ na druženje u kapetana. Za svetkovinu sv. Josipa tradicionalno se pripravljaju razne delicije. Na objede dolaze prijatelji i svojta..$^{63} \mathrm{Na} z ̌ a r d i n u^{64}$ se nalaze banci ${ }^{65} \mathrm{~s}$ tantahorijama. ${ }^{66}$ Ovi običaji sačuvani su do naših dana. ${ }^{67}$

\section{Usmene i pučke lirske pjesme}

Lirska je pjesma skupina umjetnički komponiranih lirskih slika kojima dominira osjećajnost. Te pjesme prate čovjeka od rođenja (uspavanke) pa do smrti (naricaljke). Lirske pjesme su najbrojnija usmenoknjiževna vrsta, a obuhvaćaju vjersku i svjetovnu liriku.

Blagdanskim raspoloženjem i prigodnim pjesmama izražava se radost što se po Isusovu rođenju očitovala dobrota Boga, našega Spasitelja, i njegova ljubav prema ljudima. Značajke jezika božićnih lirskih pjesama su: emocionalnost, simboličnost, slikovitost i konkretnost. Narodni pjevač u Baču slika porođenje Isusovo u štalici među marvalija, u razdrtoj štali i moli Josipa da nam užeže svijeću da ne mre od zime Isus, malo Dite:

Divica Marija Sinka porodila

U štalici, na slami među marvalija!

O blago Ditešce, moj Isuse mali,

što ćemo od zime u razdrtoj štali.

Ko će nam pomoći, ko li će nam doći,

Ko li će, moj Sinko, tebe ugrijati?

Josipe, Josipe, užeži nam sviću,

Da ne mre od zime Isus, malo Dite.

Volari, volari, stari gospodari,

Odite, vidite, di je Isus mali.68

U svim je božićnim pjesmama iznimno snažan lirski efekt. U tim pjesmama ogleda se veselje jer se rodio Spasitelj i Otkupitelj svijeta, ali se iskazuje i briga jer je malom Isusu hladno. Svake se godine na blagdan Sveta tri kralja u crkvi

\footnotetext{
${ }^{61}$ Finiju - završili su.

${ }^{62}$ Gre - ide.

${ }^{63}$ Svojta - rodbina.

${ }^{64}$ Žardin - park.

${ }^{65}$ Banci - drvene klupe.

${ }^{66}$ Tantahorije - bižuterija.

${ }^{67}$ Ivana Prižmić zapisala je u Veloj Luci 2009. godine, a kazala joj je Marija Cetinić, rođena Franulović 1937. godine (Ivana Prižmić, Tradicijska baština i književnost u Veloj Luci, diplomski rad, Split, Filozofski fakultet Sveučilišta u Splitu, 2010, 27).

${ }^{68}$ Krešimir MLAČ (sastavio), Zlatna knjiga hrvatske narodne lirike, Zagreb, Matica hrvatska, 1972, 118.
} 
sv. Ivana Krstitelja u Postirama na Braču izvodi pjesma Kad se Bog čovik učini, a kazivačica navodi da je pjesma stara pet stoljeća. Narodni je pjevač u pedeset katrena opjevao dolazak Stvoritelja i Otkupitelja svijeta. Snažne su lirske slike koje taj najradosniji čin u kršćanstvu oslikavaju mnogim čudesima koja su se dogodila: noć se u dan promijeni; andeli s neba sletiše; jasno je sunce zasjalo, a tamnost noćna pobjegla; živine su Stvoritelja poznale, a davolu je snaga izginula. Na svijetlom istoku zvijezda se ukazaše i kad je vidješe tri kralja: Gašpar, Melkior i Baltazar se vele čudiše. Kraljevi su shvatili da se kraljić porodi, koji će $s$ nami vladati. Spremili su vojsku i službu, $i$ dobre konje vrh svega, a zvijezda im je bila u družbi. Kad su stigli u Jeruzalem, kraljevi su pitali građane: $U$ ke se rodi Bog strane / $i$ kstanu put im da kažu.

Za dolazak kraljeva čuo je srditi Irud, hitro je krenuo prema njima te ih pitao kamo su pošli. Saznavši od kraljeva da se rodio Isus, Irud sazva sve svoje zbore da vidi što mudraci govore gdi će se Isus roditi. U Betlem odgovoriše, / da se porodit imaše. / Irude, ti ne čudi se / jer pisma tako tumače. Zatim je Irud uputio kralje u Betlehem jer će ondje Isusa naći, ali da mu na povratku kažu gdje je Isus. Ponovno je zasjala zvijezda koja je od kraljeva pobjegla kada se pojavio Irud. Zvijezda je tri kralja dovela do spilice i ondje je zvijezda iskricam kapala.

Pred kućicom Svet Osib (Josip) šetaše i s trudom drva beraše, jer bihu dnevi studeni. Kada Osib ugleda mnoštvo od straha tužan uspreda, Mariju brzo zazove da sinka probudi i sakrije. Kralj ga je Baltazar tješio i molio da su s najboljom namjerom prišli da od nebeskoga poroda prime blagu utjehu. Osib drhćući otvori vrata, kralji s glave skinuše predragocjene te krune, padnu na koljena te svaki od njih Božjeg sina nadari. Isus tada kraljevima udijeli blagoslove, a Bog im objavi da se ne vraćaju istim putem.

Pjesma završava molitvom upućenom Isusu da nama grijehe oprosti i neka se duša napuni njeg’vom blagom milosti. ${ }^{69}$

Narodni pjesnik opisao je staroga patrijarha koji je Djevici Mariji obznanio da je njezin zaručnik Josip:

»Vezak vezla Divica Marija,

baš u bašči pod žutom narančom.

$K$ njoj dolazi stari svećeniče,

pa je njojzi tio besidio:

Dite moje, Divice Marijo, obećao sam s tobom pobrinuti, pa ti evo nađe zaručnika.

Pobožan je kao patrijar, stidljiv je od svake divojke.«

Marija je vezak odložila,

${ }^{69}$ Usp. Marko DRAGIĆ, Sveta tri kralja u hrvatskoj tradiciji, Crkva u svijetu, 42 (2007) 1, 112115. 
otvorila dva nebeska oka, pa je njemu tio besidila: »Srce moje samo Bogu leti, udaja mi nije na pameti.« Starac ode, a Jozip se javi: »Sestro moja, Divice Marijo, vele meni da se s tobom ženim.« Marija mu puna sriće vrati: »O Jozipe, brate ko od majke, nu milosti Boga velikoga i ja sam se njemu povirila, da Divicom vik ću vikovati. Eto sada on nas sastavijo, da bi mogli po volji božanskoj, u ljubavi živit divičanskoj." I vinčaše se dva ljiljana bila, čista, lipša, draža od anđela. Amen. ${ }^{70}$

U kršćanstvu narančino stablo simbolizira čistoću, čednost i velikodušnost. Stablo naranče često se javlja u ikonografiji Djevice Marije. ${ }^{71}$ Velolučki zborovođa skladao je novu pjesmu u čast nebeskoga zaštitnika:

\author{
Zdravo sveti Josipe, \\ zdravo naša radosti. \\ Zdravo drago sunašce \\ Isusove mladosti. \\ Tople zrake ljubavi, \\ prospi Oče za nas, \\ Blagi, sveti Josipe, \\ moli Boga za nas. \\ Čisti druže Djevičin, \\ slugo Božji prevjerni, \\ Čistog Božjeg janjeta, \\ hranitelju presmjerni. \\ Unebeskoj radosti, \\ misli, Oče, na nas, \\ Moćni, sveti Josipe, \\ moli Boga za nas. \\ Kad se život ugasi, \\ kad nas tmina pokrije,
}

\footnotetext{
${ }^{70} \mathrm{U}$ Bukovici kod Tomislavgrada zapisao sam 2003. godine, Vl. rkp. zb.

${ }^{71}$ Anđelko BADURINA (ur.), Leksikon ikonografije, liturgike $i$ simbolike zapadnog kršćanstva $i$ Uvod u ikonologiju Radovana Ivančevića, Zagreb, Kršćanska sadašnjost, 1990, 419.
} 
luč upali milosti, da nam slavu otkrije. U tim teškim borbama, budi, Oče, kraj nas, Jaki, sveti Josipe, moli Boga za nas. ${ }^{72}$

Neke pjesme sadrže više lirskih slika o sv. Josipu koji bašču gradi, a za njim Gospa cvijeće sadi:

\author{
Sveti Josip bašču gradi, \\ za njim Gospa cviće sadi, \\ bilu lalu i ružicu \\ i mirisnu ljubicu. \\ Progovara draga Gospa: \\ "Ko će ovo cviće brati, \\ bilu lalu i ružicu \\ i mirišljivu ljubicu? \\ Dušicama u raj doći, \\ rajska vrata otvoriti, \\ prave duše poštovati, \\ u nebesa Božjem Sinu, \\ našem milom Gospodinu, \\ kome neka bude hvala, \\ od postanka pa dovika. Amen! «" ${ }^{73}$
}

Ljubica (ljubičica) u kršćanstvu simbolizira poniznost, a sv. Bernard Djevicu Mariju opisuje kao poniznu ljubičicu. ${ }^{74}$ Lala $^{75}$ simbolizira ljepotu, bogatstvo i raskoš. Budući da cvjeta u proljeće simbolizira i novi početak. Crvena ruža u kršćanstvu simbolizira mučeništvo, a bijela ćudorednu čistoću. ${ }^{76}$

\title{
4. Molitve i preporuke sv. Josipu
}

Budući se prema crkvenome učenju godišnje vrijeme dijeli na advent, Božić, korizmu, Uskrs i vrijeme kroz godinu molitvene pjesme mogu se klasificirati na: adventske i božićne, korizmene i uskrsne i svetačke. Toj klasifikaciji mogu

\footnotetext{
${ }^{72}$ Prižmić, nav. dj.

${ }^{73}$ U Uskoplju sam zapisao 1997. godine, Vl. rkp. zb.

${ }^{74}$ Usp. Badurina, nav. dj., 388.

${ }^{75}$ Lála - tulipan.

${ }^{76}$ Usp. Badurina, nav. dj., 516.
} 
se dodati: molitvene pjesme Isusu, molitvene pjesme Mariji, jutarnje, večernje, obredne, prigodne, svetačke, općinske (priporuke). ${ }^{77}$

U bihaćkom kraju poznata je starinska molitva koju vjernici upućuju Isusu, Mariji i Josipu:

\author{
O dvostrukom to predragom zalogu, \\ vrućo te molim, \\ da mi tu milost isprosiš, \\ da od svake nečistoće, \\ čista srca sačuvam \\ i čistim srcem Isusa i Mariju služim! \\ Isuse, Marijo i Josipe, \\ u ruke vaše predajem \\ srce i dušu svoju. Amen. ${ }^{78}$
}

Vjernici u molitvama sv. Josipa nazivaju lijerovim ${ }^{79}$ cvijetom:

O, Josipe svet, ko oca te svog, poštivao Bog. Ti lijerov si cvijet, $o$, Josipe svet.

Zauzmi se za nas, milosrdan, jak, da veliki mrak, razasja nam Isus i rana $M u$ pet, o, Josipe, svet.

Za posljednju borbu, nek' Isusov kruh, ojača nam duh i lako će biti, pobijedit i mrijet, o, Josipe, svet. ${ }^{80}$

\footnotetext{
${ }^{77}$ Usp. Marko DRAGIĆ, Duša tilu besidila. Hrvatske pučke molitvene pjesme iz Bosne i Hercegovine, Baška Voda, Mala nakladna kuća sv. Jure, 1997.

${ }^{78}$ Zapisao sam u bihaćkom kraju u prosincu 1995. godine, Vl. rkp. zb.

${ }^{79}$ Lijer - ljiljan.

${ }^{80}$ Svjetlana Čelan zapisala je 2013. godine. Molitvu joj je kazala Bisera Čelan, djev. Ćurić, iz Vrkašića, 1947. godište, a molitvu je naučila od svoje majke Danke Ćurić, djev. Čelan, 1915. godište, iz Kralja (usp. Svjetlana Čelan, Usmeno-književna baština u suvremenim zapisima iz bihaćkoga kraja, diplomski rad, Mostar, Filozofski fakultet Sveučilišta u Mostaru, 2013, 41).
} 
Ljiljan je znak čistoće i stoga je cvijetom blažene Djevice Marije. U ranoj kršćanskoj umjetnosti ljiljan je bio oznakom svetih djevica. Ljiljan među trnjem simbolizira bezgrješno začeće blažene Djevice Marije. U renesansnom slikarstvu arkanđeo Gabrijel pri Navještenju drži ljiljan u ruci. Pokatkad se i dijete Isus prikazuje s kiticom ljiljana koju pruža nekom svecu. Ljiljan je oznakom mnogih svetaca, primjerice: sv. Josipa, sv. Klare, sv. Dominika, sv. Franje, sv. Antuna Padovanskog. ${ }^{81}$ Ljiljan se u Bibliji spominje 20 puta.

Hrvatski katolički narod sv. Josipa naziva Spasiteljevim poočimom koji je smjerno živio brižno i vjerno hraneći Isusa i Mariju:

Josipe, o milo ime,

Spasiteljev poočime,

kom na brizi Bog bi sam,

vječnog Oca zastupniče,

Majke Božje zaručniče,

svim te srcem pozdravljam.

Koju slast si okušao,

kakvom li se srećom sjao,

hraneć Dite Božje.

Živio si tako smjeran

kao čuvar brižan, vjeran,

Isusa i Marije. ${ }^{82}$

U molitvama sv. Josip je tihi zanatlija, ljiljanov cvijet, milosrdan i jak:

Zanatlijo tihi,

ko oca te svog,

poštivao Bog,

Ti zaručnik Djevin,

Ti ljiljanov cvijet,

o Josipe svet.

Zauzmi se za nas,

milosrdan i jak,

da veliki mrak,

razasja nam Isus

i rana mu pet, o Josipe svet. ${ }^{83}$

Isusu, Mariji i sv. Josipu narod se moli za laku smrt:

Isuse, Marijo i Josipe sveti, mir dajte mi duši,

\footnotetext{
${ }^{81}$ Usp. Badurina, nav. dj., 387-388.

${ }^{82}$ Zapisao sam u Tomislavgradu 2010. godine, Vl. rkp. zb.

${ }^{83}$ Isto.
} 
svjetlost pameti, srce i svoju dušu vami darujem.

Vaš sveti blagoslov u pomoć zazivljem.

Daj obitelji sveta,

da srcem, ustima vapijući

sveto ime dušu ispustim.

O slatki moj Isuse

budi nam u svim mislima

i riječima $i$ dijelima.

Sveti Bože, sveti Jaki, sveti neumrli, smilujte nam se.

Navedena molitva moli se tri puta i prekriži se na čelu ustima i prsima. ${ }^{84}$

Među najčešćim molitvama sv. Josipu molitva je O Jozipe, Oče sveti. U duvanjskom kraju moli se molitva:

O Jozipe, oče sveti, čuvaj kuću i posveti.

Sva obitelj nek se složi, sveta ljubav nek se množi, mir, veselje knami svrati i stra Božji nek nas prati. Žiće podaj da nam plodi i put raja da nas vodi. Čuj nam Oče molbu vruću, Ti nas čuvaj i svu kuću.

Tebi ključe pridajemo, Gospodarom priznajemo.

Sve što kući može nauditi, ti se Oče udostoj odstraniti, u prisvetom srcu ostraniti. Ti nas Oče sve nastani da živimo svi na svitu ka ti Oče u Nazaretu. Amen. ${ }^{85}$

Varijacija te molitve molila se svaku večer poslije krunice u Biogracima kod Širokoga Brijega, ${ }^{86}$ livanjskom kraju i mnogim drugim mjestima. U duvanj-

\footnotetext{
${ }^{84} \mathrm{Na}$ Hotnju Hutovskom 1998. godine priopćila je Janja Konjevod, djev. Trojić, rođ. 1944. godine, Vl. rkp. zb.

${ }^{85}$ Anamarija Buljan zapisala je 2016. godine u Biteliću kod Sinja. Kazala joj je Marija Buljan, rođena 1936. godine u Biteliću (Anamarija Buljan, Usmenoknjiževna i crkveno-pučka baština u sinjskom kraju, završni rad, Split, Filozofski fakultet u Splitu, 2019, 12).

${ }^{86}$ Godine 1999. zapisao sam u Biogracima kod Širokoga Brijega, Vl. rkp. zb.
} 
skom kraju na zajedničkoj večernjoj molitvi ukućani na početku izmole Anđeo Gospodnji te tri puta Oče naš, Zdravo Marija i Slava Ocu na čast Blažene Djevice Marije:

Djevice čista prije poroda, moli za nas.

Djevice čista u porodu, moli za nas.

Djevice čista poslije poroda, moli za nas.

Zatim se izmoli po jedan Oče naš, Zdravo Marijo i Slava Ocu na čast anđela čuvara, na čast Imena Isusova i Imena Marijina, na čast Presvetoga Trojstva. 87 Poslije toga se moli zahvala Bogu Ocu na stvorenju, Sinu na otkupljenju, Duhu na posvećenju. Slijedi molitva jednog Očenaša na čast Božje providnosti, te na čast sv. Frane i sv. Josipa:

Ta dva Božja ugodnika,

na času smrti naše,

da nam isprose svećenika.

Da se mognemo čisto i pravedno,

ispovidit na času smrti svoje.

Da podemo izmireni,

sovoga svita na drugi. ${ }^{88}$

Svetoj obitelji hrvatski katolici mole se da dušu ispuste vapijući ime Svete obitelji:

Isuse, Marijo i Josipe,

sveti miru,

dajte nam duši

svetost i pamet;

Vama svoju dušu darivamo,

a Vaš sveti blagoslov,

u pomoć zazivamo.

O daj Obitelji sveta;

da ja srcem $i$ dušom,

vapijući tvoje ime

dušu ispustim. Amen. ${ }^{89}$

Isusu, Mariji i Josipu vjernici se mole i u jutarnjim molitvama:

Isuse, Marijo i Josipe sveti,

mir dajte duši mi

i svjetlost pameti!

\footnotetext{
${ }^{87}$ U Mrkodolu kod Tomislavgrada zapisao sam 2007. godine, Vl. rkp. zb.

${ }^{88}$ Isto.

${ }^{89}$ U Buni kod Mostara zapisao sam 2006. godine, Vl. rkp. zb.
} 
Vama svoje srce

$i$ dušu predajem.

Vaš sveti blagoslov

u pomoć zazivam.

Daj, obitelji sveta,

da srcem i ustima vapeći

Tvoje ime dušu ispustim.

Slatki moj Isuse,

budi mi danas

u svim mojim mislima

i riječima i djelima!

Što god danas budem pomislila

sve neka bude

iz čiste ljubavi prema tebi.

Na tvoju čast

$i$ slavu preljubljenog sina tvoga,

Gospodina našega Isusa Krista! ${ }^{10}$

U molitvama sv. Josip naziva se lijepim cvijetom:

O Jozipe, lipi cvite,

sad $i$ vazda pomozi me.

Duša moja gorko cvili,

iz dubine srca moga,

di uvridi Boga svoga.

Ja se kajem.

Isusu, Josipu i Mariji vjernici daruju svoje srce i preporučuju se da na času končanja budu uz njih:

Isuse, Josipe i Marijo, vama darujem srce moje, dušu moju i tijelo moje. Isuse, Josipe i Marijo, Kad bude najposlijednji, čas končanja života moga, budi uza me i pomozi mene.

Isuse, Josipe i Marijo, nek se dijeli duša moja iz prsiju u miru s vama.

${ }^{90}$ Danijela Bošković zapisala je 2005. godine, a kazala joj je Stana Bošković, djev. Palameta, rođ. 1920. godine (Danijela BOŠKOVIĆ, Etnologija i antropologija u suvremenoj etnografiji stolačkog kraja, diplomski rad, Mostar, Filozofski fakultet Sveučilišta u Mostaru, 2006, 9). 
Blagoslovljeno i sveto neoskvrnjeno začeće,

Blažene prečiste Djevice Marije,

Majke Isusove.

Koliko smo prošli dana sagriješili,

Svemogućega Boga uvrijedili,

da unaprijed ne sagriješimo,

Svemogućega Boga ne uvrijedimo.

Mir i blagoslov Boga - Oca svemogućega.

Sišao na nas i prebivao među nama. Amen. ${ }^{91}$

Za prosvjetljenje i pomoć na putu moli se molitva:

Isuse, Marijo i Josipe,

sveti mir dajte mi duši,

svitlost i blagoslov, pomoć i pamet.

Vama svoje srce, ruke darujem.

Kao što sveti Franjo u noći caruje.

O ljubljeni, moj mili, Isuse,

svom me snagom čuvaj, ljubi.

Nadgledaj put,

- kojim ću danas ja ići - putem kriposti.

Sva svoja djela, misli,

riči svojom ti prosvijetli mene. Amen. ${ }^{92}$

Svetom Josipu, zaštitniku radnika i zaštitniku duša čija je zaštita snažna i spremna pred Božjim prijestoljem moli se:

$O$, sveti Josipe,

čija je zaštita tako velika

tako snažna i tako spremna

pred prestoljem Božjim.

Tebi povjeravam sve svoje,

želje i potrebe.

$O$, sveti Josipe,

svojom moći zagovaraj me

$i$ isprosi od Božjeg Sina

Gospodina našeg Isusa Krista

sve duhovne vrijednosti,

tako da posjedujući ovde na zemlji

tvoju nebesku moć

mogu prikazati svoju zahvalnost

\footnotetext{
${ }^{91}$ Zapisao sam 2000. godine u Crnim Lokvama kod Širokoga Brijega, Vl. rkp. zb.
}

${ }^{92}$ Isto. 
$i$ štovanje nebeskom ocu.

$O$, sveti Josipe,

neće mi nikad biti dosta

promatrati Isusa kako spava

na tvojim rukama.

Ne osudujem se približiti

dok on spava na tvom srcu.

Pritisni ga na tvoja prsa

i poljubi ga za mene,

u lipu glavu.

I zamoli ga da mi

vrati taj poljubac

u času moje smrti

kod zadnjeg izdisaja.

O sveti Josipe,

zaštitniče duša,

koje dolaze u vičnost

moli za nas. Amen..$^{93}$

U hrvatskoj tradiciji preporuke se mole za vrijeme zajedničke (općinske) molitve. U mnogim preporukama vjernici se preporučuju sv. Josipu:

Sveti Josipe,

pravedni zaručniče Marijin.

Ti dušu moju zaruči

$i$ Gospodu Bogu priporuči

i od njega ne odluči. ${ }^{94}$

Vjernici se preporučuju sv. Jozipu i sv. Frani da im dodijeli misnika u času smrti da se mogu ispovjediti, dušu očistiti i svete sakramente primiti:

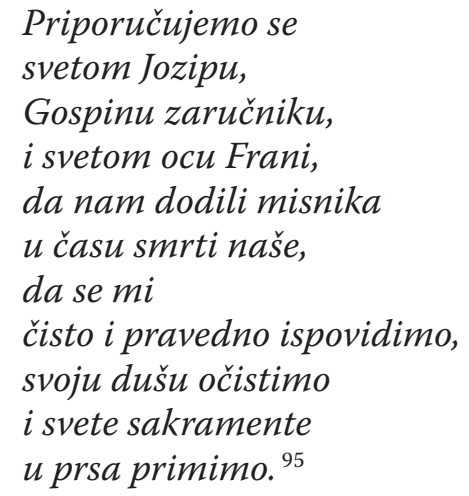

\footnotetext{
${ }^{93} \mathrm{U}$ selu Letka, u duvanjskom kraju, zapisao je sam 2002. godine, Vl. rkp. zb.

${ }^{94}$ U Prugovu kod Klisa snimio sam 2005. godine, Vl. rkp. zb.

${ }^{95} \mathrm{U}$ Buni kod Mostara zapisao sam 2006. godine, Vl. rkp. zb.
} 
U preporukama moli se Oče naš i Zdravo Marijo i preporučuje sv. Frani i sv. Jozipu:

\author{
Očenaš i Zdravo Mariju \\ svetom Frani, \\ svetom Jozipu, \\ da nam isprati misnika \\ i propovidnika, \\ da se čisto \\ i pravedno ispovidimo, \\ pokoru izmolimo, \\ $s$ Bogom se pomirimo, \\ od grija odrišimo. ${ }^{96}$
}

Više je varijacija molitvi koje narod upućuje sv. Josipu i sv. Franji. Takva je, primjerice molitva iz Rujna kod Širokoga Brijega:
Na čast svetog Josipa i Franje,
da se na času smrti,
mognem čisto i pravedno ispovidit,
svoju dušu očistit od svakoga grija,
navlastito smrtnoga
i da sa ovog svita pođen na bolji. ${ }^{97}$

Više je molitvi u kojima se vjernici preporučuju Srcu Isusovu, Srcu Marijinu i Srcu Josipovu:

\author{
Očenaš i Zdravo Mariju \\ Srcu Isusovu, \\ Srcu Marijinu, \\ i Srcu Jozipovu, \\ da tri slatka Srca slavna \\ prosvitle naša srca \\ svojim srcem, \\ da budemo čisti \\ i u duši i u tilu, \\ da očiste našu dušu \\ od svakoga grija \\ i navrata smrtnoga. ${ }^{98}$
}

\footnotetext{
${ }^{96}$ Isto.

${ }^{97}$ U selu Rujan kod Širokoga Brijega zapisao sam 2004. godine, Vl. rkp. zb.

${ }^{98}$ Zapisao sam 2006. godine u Buni kod Mostara, Vl. rkp. zb.
} 
Usmene lirske pjesme komponirane su najčešće osmercima s cezurom iza četvrtoga sloga. Nekoliko je navedenih pjesama komponirano slobodnim stihom u kojem se prepleću sedmerci, deseterci i dvanaesterci. Stihovi se različito rimuju. Primjerice, u pjesmi Sveti Josip bašču gradi stihovi se rimuju aabbcdeefgghij. U pjesmama i molitvama najčešći su epiteti, primjerice: drago sunašce, bilu lalu i ružicu, mirisnu ljubicu, mirišljivu ljubicu, slatki moj Isuse. Česte su i uvećanice, primjerice: prevjerni, presmjerni, preljubljenog sina tvoga.

\section{Zaključak}

Sveti Josip je višestruki zaštitnik. Hrvatski sabor je 1687. godine proglasio sv. Josipa zaštitnikom Hrvatskog kraljevstva, a time i cijelog hrvatskog naroda. U hrvatskoj tradicijskoj kulturi posebno se štuje kao zaštitnik obitelji, djevojaka, žena i umirućih. U Hercegovini sv. Josipa štuje se kao zaštitnika siromaha.

Svetkovinu sv. Josipa karakteriziraju pobožnosti, sudjelovanje u procesiji, odlazak na svetu misu te pučka veselja. Procesije su komunisti zabranili 1952. godine te su se od te godine mogle održavati samo u dvorištu crkve. Nakon demokratskih promjena $\mathrm{u}$ mnogim mjestima revitalizirane su procesije kroz gradove i sela. Revitalizirana su i velika pučka slavlja.

Za vrijeme turske okupacije djevojke i mladići u dobi od 13 do 16 godina podvrgavali su se bolnom tetoviranju na svetkovinu sv. Josipa. Djevojke i mladići tetovirali su križeve na rukama, prsima, čelu. Taj običaj nastao je da bi se djevojke i žene sačuvale od turskih napasnika i da bi izbjegle pravo prve bračne noći. Mladići su tetovirali križeve da bi pokušali izbjeći odvođenje u janjičare (danak u krvi) a ako bi bili odvedeni križ im je bio podsjetnik tko su. Cilj tetoviranja križeva bio je i da se spriječi prelazak na islam i trajno sačuva vjerski identitet. Običaj tetoviranja križeva sačuvao se do pedesetih godina 20. stoljeća.

Navedene pobožnosti, običaji, usmene lirske pjesme, molitve i preporuke dokaz su snažene vjere hrvatskoga naroda koji je sačuvao svoju vjeru usprkos višestoljetnim nenarodnim vlastima. Često se u usmenim lirskim pjesmama štuje svetost obitelji i njezin zaštitnik sv. Josip. Neke od tih pjesama imaju antologijsku vrijednost. 


\section{Marko Dragić* \\ The Veneration of Saint Joseph in Croatian Ecclesial-folk Heritage \\ Summary}

Paper discusses the life of Saint Joseph of Nazareth, Virgin Mary's husband and Jesus Christ's non-biological father. Gospels do not cite a single word by him, and what we know about him is mostly contained in the first two chapters of the Gospels by Matthew and Luke. In 1687 Croatian Parliament named St. Joseph the patron of the Kingdom of Croatia, and thus the whole Croatian nation. He is the patron of many countries, towns, universities, hospitals, schools, churches and other institutions. He is also the patron of families, fathers, children, youth, orphans, virginity and purity, patron of good death, shelters and those who are looking for them, travellers and refugees, lumberjacks, wheelmakers, carpenters, woodworkers, workers and artisans, engineers, immigrants, dying people and gravediggers. The feast day of St. Joseph in the Croatian ecclesialfolk heritage is celebrated with devotions, vows, novenas and tridua, processions, holy masses, folk festivities. During the Turkish occupation Croatian Catholic girls aged from 13 to 16 years performed the ritual of križićanje (the tattooing of crosses on hands and/or forehead and/or chest). Croatian Catholic boys tattooed crosses on their shoulders to have a permanent reminder of their heritage and faith when the Turks take them to become janissaries. Croatian Catholic people even nowadays remember and tell oral lyrical poems heard from their ancestors. People make ancient prayers to St. Joseph, the multiple protector, which were prayed by our foremothers and forefathers that passed away long time ago. The believers recommend themselves to St. Joseph in joint family prayers and in different other occasions.

Key words: multiple protector, oral lyrical religious poems, prayers, recommendations, St. Joseph.

(na engl. prev. Nikola Sunara)

\footnotetext{
* Marko Dragić, PhD, Full Prof., University of Split, Faculty of Humanities and Social Sciences, Head of the Department for Literature and Culture and the head of the Module for Literature and Culture at the Postgraduate Doctoral Study in Humanities; Address: Poljička 35, HR21000 Split, Croatia; E-mail: mdragic@ffst.hr.
} 